\title{
KAJAN HUKUM \\ ATAS PERATURAN MENTERI PERHUBUNGAN NOMOR PM 90 TAHUN 2015 \\ TENTANG PENGENDALIAN PENGOPERASIAN PESAWAT UDARA TANPA AWAK DI RUANG WILAYAH UDARA YANG DILAYANI INDONESIA
}

Oleh :

Selamat Lumban Gaol, SH, MKN.

(Email : selamatlumbangaol@gmail.com)

Dosen Tetap Fakultas Hukum Universitas Suryadarma, aktif di LKBH Unsurya, anggota PERADI (Perhimpunan Advokat Indonesia) dan anggota HKHPM (Himpunan Konsultan Hukum Pasar Modal)

\begin{abstract}
:
Pesawat udara tanpa awak (drone) merupakan benda terbang sebagai wahana nir awak dengan kemampuan melakukan terbang otonom secara penuh dan wahana yang dikendalikan secara jarak jauh oleh manusia yang digunakan untuk menyelesaikan suatu pekerjaan manusia. Untuk menjaga keselamatan penerbangan Pesawat udara tanpa awak (drone) di ruang udara yang dilayani Indonesia dari kemungkinan bahaya (hazard) yang ditimbulkan karena pengoperasiannya, Menteri Perhubungan mengeluarkan Peraturan Menteri No. 90 Tahun 2015 Tentang Pengendalian Pengoperasian Pesawat Udara Tanpa Awak Di Ruang Udara yang Dilayani Indonesia. Apabila dicermati secara seksama Undang-undang Penerbangan, belum menemukan pendelegasian dari Undang-undang Penerbangan kepada Menteri Perhubungan untuk mengatur pengendalian pengoperasian pesawat udara tanpa awak (drone). Akan tetapi apabila ketentuan UU Pembentukan Peraturan Perundang-undangan dihubungkan dengan ketentuan UU Kementerian Negara serta dihubungkan pula dengan UU Penerbangan, maka secara materiil melekat kewenangan pada menteri perhubungan untuk melakukan pengaturan pengendalian pengoperasian pesawat udara tanpa awak (drone), dalam bentuk suatu peraturan menteri perhubungan.
\end{abstract}

Kata Kunci : Pesawat Udara, tanpa awak, ruang wilayah, Peraturan Menteri. 


\section{PENDAHULUAN}

Kata "drone" saat ini sangat lazim digunakan masyarakat sejak Presiden Jokowi setahun terakhir mempopulerkannya, drone merupakan benda terbang sebagai wahana nir awak dengan kemampuan melakukan terbang otonom secara penuh dan wahana yang dikendalikan secara jarak jauh oleh manusia yang digunakan untuk menyelesaikan suatu pekerjaan manusia. ${ }^{1}$

Penggunaan pesawat tanpa awak (drone) kini banyak dilakukan masyarakat sipil untuk berbagai aktivitas. Untuk menjaga keselamatan penerbangan, Menteri Perhubungan mengeluarkan Peraturan Menteri No. 90 Tahun 2015 Tentang Pengendalian Pengoperasian Pesawat Udara Tanpa Awak Di Ruang Udara yang Dilayani Indonesia, yang diberlakukan sejak 12 Mei 2015 tersebut dalam rangka menjaga keselamatan operasional penerbangan di ruang udara yang dilayani Indonesia dari kemungkinan bahaya (hazard) yang ditimbulkan karena pengoperasian drone. ${ }^{2}$

Secara umum drone dibagi dalam dua kategori, yaitu kategori drone kelas berat dengan berat pesawat $150 \mathrm{~kg}$ ke atas, dan drone ringan dengan berat maksimal $150 \mathrm{~kg}$. Pemakaian drone berat untuk tujuan sipil biasanya diatur oleh otoritas penerbangan sipil

1"Perlukah adanya Legislasi Drone Sipil?," http://www.koran-

sindo.com/read/1013173/152/perlukah-adanyalegislasi-drone-sipil-1434424227

2 "Pengaturan Drone Dilakukan Untuk

Keselamatan Penerbangan,"

http://www.dephub.go.id/berita/baca/pengaturandrone-dilakukan-untuk-keselamatan-

penerbangan/?cat $=\mathrm{QmVyaXRhfHN} 1 \mathrm{Y} 3 \mathrm{Rpb} 24 \mathrm{tNjU}$ $=$ nasional, seperti dalam kesepakatan International Civil Aviation Organization (ICAO), sementara untuk drone kelas ringan, sampai saat ini secara internasional masih belum jelas aturannya. $^{3}$

Apabila dicermati UU Penerbangan ${ }^{4}$ belum ditemukan istilah dan atau pengaturan baik secara khusus atau tidak berkenaan dengan pesawat udara tanpa awak (drone atau pesawat nir awak) baik dalam salah satu pasal atau dalam salah satu ayat ataupun dalam suatu bab tersendiri dalam UU Penerbangan.

Dari uraian diatas timbul suatu kegelisahan berkenaan dengan kedudukan Permenhub No. 90 Tahun 2015 tersebut ditinjau dari segi hukum.

Berdasarkan latar belakang masalah tersebut, peneliti melakukan penelitian dengan judul "Kajian Hukum Atas Peraturan Menteri Perhubungan Nomor PM 90 Tahun 2015 Tentang Pengendalian Pengoperasian Pesawat Udara Tanpa Awak di Ruang Wilayah Udara yang Dilayani Indonesia."

\section{RUMUSAN MASALAH}

Berdasarkan hal tersebut diatas, adapun permasalahan yang akan dikaji dalam penelitian ini dibatasi pada pokoknya sebagai berikut:

\footnotetext{
"Penggunaan Drone Sipil: Pro atau Kontra?," http://citizendaily.net/penggunaandrone-sipil-pro-atau-kontra/.

${ }^{4}$ Indonesia, Undang-Undang Tentang Penerbangan, UU Nomor 1 Tahun 2009. Lembaran Negara Republik Indonesia Tahun 2009 Nomor 1, Tambahan Lembaran Negara Republik Indonesia Nomor 4956. Untuk selanjutnya dalam penulisan ini akan dan cukup disebut "UU Penerbangan" atau "UU Nomor 1 Tahun 2009"
} 
1. Apakah menteri perhubungan berwenang mengatur Pengendalian Pengoperasian Pesawat Udara Tanpa Awak (Drone) di Ruang Wilayah Udara yang dilayani Indonesia?

2. Apakah Peraturan Menteri Perhubungan Nomor PM 90 Tahun $2015 \quad$ Tentang Pengendalian Pengoperasian Pesawat Udara Tanpa Awak di Ruang Wilayah Udara yang Dilayani Indonesia telah memenuhi ketentuan ilmu dan teknik pembentukan perundangundangan?

\section{PEMBAHASAN}

1. Kewenangan perhubungan Pengendalian Pesawat Udara Tanpa Awak (Drone) di Ruang Wilayah Udara yang Dilayani Indonesia?

Sumber kewenanangan seorang menteri membentuk suatu peraturan menteri adalah wewenang atribusi (atributie bevoegdheid). Wewenang atribusi (atributie bevoegdheid) adalah wewenang menteri yang diperoleh dari dan telah diatur dalam peraturan perundang-undangan yang berlaku. ${ }^{5}$

Peraturan perundang-undangan yang memberikan kewenangan kepada menteri perhubungan melakukan pengaturan hukum dengan menerbitkan peraturan menteri tentang Pengendalian Pengoperasian Pesawat Udara Tanpa Awak (Drone) di Ruang Wilayah Udara yang Dilayani Indonesia, antara lain, adalah sebagai berikut:

\section{a. UU Kementerian Negara}

Menteri dalam perspektif UU Kementerian Negara adalah pembantu presiden yang memimpin kementerian yang berada di bawah dan bertanggungjawab kepada Presiden. $^{7} \quad$ Dalam melaksanakan tugasnya, kementerian yang melaksanakan urusan pemerintahan tertentu menyelenggarakan fungsi perumusan, penetapan, dan pelaksanaan kebijakan di bidangnya. $^{8}$
${ }^{5}$ Sadjijono, Memahami Beberapa Bab Pokok Hukum Administrasi, Cet. 1, (Yogyakarta : Laksbang Pressindo, 2008), hlm. 59.

${ }^{6}$ Indonesia, Undang-Undang Tentang Kementerian Negara, UU Nomor 39 Tahun 2008. Lembaran Negara Republik Indonesia Tahun 2008 Nomor 116, Tambahan Lembaran Negara Republik Indonesia Nomor 4916. Untuk selanjutnya dalam penulisan ini akan dan cukup disebut "UU Kementerian Negara" atau "UU Nomor 39 Tahun 2008"

${ }^{7}$ UU Kementerian Negara, Pasal 1 angka 2 "Menteri Negara yang selanjutnya disebut Menteri adalah pembantu Presiden yang memimpin Kementerian." Pasal 3 "Kementerian berada di bawah dan bertanggung jawab

\begin{abstract}
kepada Presiden."
${ }^{8} \mathrm{UU}$ Kementerian Negara, Pasal 3 "Kementerian berada di bawah dan bertanggung jawab kepada Presiden." Pasal 4 "(1) Setiap Menteri membidangi urusan tertentu dalam pemerintahan. (2) Urusan tertentu dalam pemerintahan sebagaimana dimaksud pada ayat (1) terdiri atas: a. urusan pemerintahan yang nomenklatur Kementeriannya secara tegas disebutkan dalam Undang-Undang Dasar Negara Republik Indonesia Tahun 1945. b. urusan pemerintahan yang ruang lingkupnya
\end{abstract}


Dalam menyelenggarakan fungsi perumusan, penetapan dan pelaksanaan kebijakan di bidangnya tersebut termasuk kewenangan untuk melakukan pengaturan hukum berkenaan dengan pelaksanaan tugasnya.

\section{b. UU Pembentukan Peraturan Perundang-Undangan ${ }^{9}$}

Suatu peraturan menteri diakui keberadaannya dan mempunyai kekuatan hukum mengikat sepanjang diperintahkan oleh Peraturan
Perundang-undangan yang lebih tinggi atau dibentuk berdasarkan kewenangan. ${ }^{10}$

Peraturan Menteri adalah peraturan yang ditetapkan oleh menteri berdasarkan materi muatan dalam rangka penyelenggaraan urusan tertentu dalam pemerintahan. ${ }^{11}$

Hal ini berarti Menteri membuat dan menerbitkan suatu peraturan menteri apabila hal tersebut diperintahkan secara tegas disebutkan dalam Undang-Undang Dasar Negara Republik Indonesia Tahun 1945, dan c. urusan pemerintahan dalam rangka penajaman, koordinasi, dan sinkronisasi program pemerintah." Pasal 5 "(1) Urusan pemerintahan sebagaimana dimaksud dalam Pasal 4 ayat (2) huruf a meliputi urusan luar negeri, dalam negeri, dan pertahanan. (2) Urusan pemerintahan sebagaimana dimaksud dalam Pasal 4 ayat (2) hurufb meliputi urusan agama, hukum, keuangan, keamanan, hak asasi manusia, pendidikan, kebudayaan, kesehatan, sosial, ketenagakerjaan, industri, perdagangan, pertambangan, energi, pekerjaan umum, transmigrasi, transportasi, informasi, komunikasi, pertanian, perkebunan, kehutanan, peternakan, kelautan, dan perikanan. (3) Urusan pemerintahan sebagaimana dimaksud dalam Pasal 4 ayat (2) huruf c meliputi urusan perencanaan pembangunan nasional, aparatur negara, kesekretariatan negara, badan usaha milik negara, pertanahan, kependudukan, lingkungan hidup, ilmu pengetahuan, teknologi, investasi, koperasi, usaha kecil dan menengah, pariwisata, pemberdayaan perempuan, pemuda, olahraga, perumahan, dan pembangunan kawasan atau daerah tertinggal." Pasal 6 "Setiap urusan pemerintahan sebagaimana dimaksud dalam Pasal 5 ayat (2) dan ayat (3) tidak harus dibentuk dalam satu Kementerian tersendiri." Pasal 7 "Kementerian mempunyai tugas menyelenggarakan urusan tertentu dalam pemerintahan untuk membantu Presiden dalam menyelenggarakan pemerintahan negara." Pasal 8 “(1) Dalam melaksanakan tugasnya, Kementerian yang melaksanakan urusan sebagaimana dimaksud dalam Pasal 5 ayat (1) menyelenggarakan fungsi: a. perumusan, penetapan, dan pelaksanaan kebijakan di bidangnya.; $b$. pengelolaan barang milik/kekayaan negara yang menjadi tanggung jawabnya.; c. pengawasan atas pelaksanaan tugas di bidangnya; dan d. pelaksanaan kegiatan teknis dari pusat sampai ke daerah. (2) Dalam melaksanakan tugasnya, Kementerian yang melaksanakan urusan sebagaimana dimaksud dalam Pasal 5 ayat (2) menyelenggarakan fungsi: a. perumusan, penetapan, dan pelaksanaan kebijakan di bidangnya; $b$. pengelolaan barang milik/kekayaan negara yang menjadi tanggung jawabnya; c. pengawasan atas pelaksanaan tugas di bidangnya; $d$. pelaksanaan bimbingan teknis dan supervisi atas pelaksanaan urusan Kementerian di daerah; dan e. pelaksanaan kegiatan teknis yang berskala nasional. (3) Dalam melaksanakan tugasnya, Kementerian yang melaksanakan urusan sebagaimana dimaksud dalam Pasal 5 ayat (3) menyelenggarakan fungsi: a. perumusan dan penetapan kebijakan di bidangnya; $b$. koordinasi dan sinkronisasi pelaksanaan kebijakan di bidangnya; $c$. pengelolaan barang milik/kekayaan negara yang menjadi tanggung jawabnya; dan $d$. pengawasan atas pelaksanaan tugas di bidangnya."

${ }^{9}$ Indonesia, Undang-Undang Tentang Pembentukan Peraturan Perundang-undangan, UU Nomor 12 Tahun 2011. Lembaran Negara Republik Indonesia Tahun 2011 Nomor 82, Tambahan Lembaran Negara Republik Indonesia Nomor 5234. Untuk selanjutnya dalam penulisan ini akan dan cukup disebut "UU Pembentukan Peraturan Perundang-undagan" atau "UUP3" atau "UU Nomor 12 Tahun 2011"

${ }^{10}$ UU Kementerian Negara, Pasal 8 ayat (2).

${ }^{11} \mathrm{UU}$ Kementerian Negara, Penjelasan Pasal 8 ayat (2). 
dan jelas oleh peraturan perundang-undangan yang lebih tinggi atau dibentuk berdasarkan kewenangan yang melekat padanya.

Frasa "diperintahkan oleh peraturan perundangundangan" dapat dimaknai ada delegasi dari peraturan perundang-undangan yang lebih tinggi kepada menteri untuk mengatur dan menerbitkannya dalam suatu peraturan menteri.

Pendelegasian kewenangan mengatur dari peraturan perundang-undangan yang lebih tinggi kepada menteri dalam suatu peraturan menteri tersebut harus menyebut dengan tegas ruang lingkup materi muatan yang diatur dan jenis peraturan perundang - undangannya adalah peraturan menteri.

Pendelegasian kewenangan mengatur dari Undangundang kepada menteri untuk dimuat dalam suatu peraturan menteri tersebut dibatasi untuk peraturan yang bersifat teknis administratif.

\section{c. UU Penerbangan}

Pembinaan penerbangan di Indonesia berdasarkan UU Penerbangan dilakukan oleh Menteri Perhubungan. ${ }^{12}$

Pembinaan penerbangan oleh Menteri meliputi aspek pengaturan. ${ }^{13} \quad$ Aspek pengaturan yang dilakukan oleh menteri perhubungan dalam melakukan pembinaan penerbangan meliputi penetapan kebijakan umum dan teknis yang terdiri atas penentuan norma, standar, pedoman, kriteria, perencanaan, dan prosedur termasuk persyaratan keselamatan dan keamanan penerbangan serta perizinan. ${ }^{14}$

Apabila dicermati secara seksama Undang-undang Penerbangan, Peneliti belum menemukan pendelegasian dari Undang-undang Penerbangan kepada Menteri Perhubungan untuk mengatur pengendalian
${ }^{12} \mathrm{UU}$ Penerbangan Pasal 1 angka 54 "Menteri adalah menteri yang membidangi urusan penerbangan." Pasal 10 "(1) Penerbangan dikuasai oleh negara dan pembinaannya dilakukan oleh Pemerintah." Pasal 11 ayat (1) "Pembinaan sebagaimana dimaksud dalam Pasal 10 ayat (1) dilaksanakan oleh Menteri."

${ }^{13} \mathrm{UU}$ Penerbangan Pasal 10 ayat (2) "Pembinaan Penerbangan sebagaimana dimaksud pada ayat (1) meliputi aspek pengaturan, pengendalian, dan pengawasan."

${ }^{14} \mathrm{UU}$ Penerbangan Pasal 10 ayat (3) "Pengaturan sebagaimana dimaksud pada ayat (2) meliputi penetapan kebijakan umum dan teknis yang terdiri atas penentuan norma, standar, pedoman, kriteria, perencanaan, dan prosedur termasuk persyaratan keselamatan dan keamanan penerbangan serta perizinan." 
pengoperasian pesawat udara tanpa awak (drone).

Akan tetapi apabila ketentuan UU Pembentukan Peraturan Perundang-undangan dihubungkan dengan ketentuan UU Kementerian Negara serta dihubungkan pula dengan UU Penerbangan, maka secara materiil melekat kewenangan pada menteri perhubungan untuk melakukan pengaturan pengendalian pengoperasian pesawat udara tanpa awak (drone), dalam bentuk suatu peraturan menteri perhubungan.

Ditinjau dari segi kemanfaatan, pengaturan pengendalian pengoperasian pesawat udara tanpa awak (drone), dalam bentuk suatu peraturan menteri perhubungan, dmaksudkan dalam rangka menjaga keselamatan operasional penerbangan di ruang udara. yang dilayani Indonesia dari kemungkinan bahaya (hazard) yang ditimbulkan karena pengoperasian pesawat udara tanpa awak di ruang udara yang dilayani di Indonesia.
2. Permenhub Nomor PM 90 Tahun 2015 ditinjau dari ilmu dan teknik pembentukan perundangundangan

Apabila dicermati secara Permenhub No. 90 Tahun 2015 diperoleh beberapa fakta hukum sebagai berikut:

a. Landasan sosiologis yang melatarbelakangi diterbitkan Permenhub No. 90 Tahun 2015 ini pada pokoknya adalah sebagai berikut:

" bahwa dalam rangka peningkatan keselamatan penerbangan terkait pengoperasian pesawat udara tanpa awak di ruang udara yang dilayani Indonesia, perlu menetapkan Peraturan Menteri Perhubungan tentang Pengendalian Pengoperasian Pesawat Udara Tanpa Awak di Ruang Udara Yang Dilayani Indonesia." 15

b. Landasan hukum yang menjadi dasar acuan diterbitkanya Permenhub No. 90 Tahun 2015 ini pada pokoknya adalah sebagai berikut:

\section{1) Undang-undang}

Undang-undang yang mendasari terbitnya Permenhub No. 90 Tahun 2015 ini hanya satu Undang - undang saja, yaitu Undang-undang

${ }^{15}$ bagian "Mengingat," Permenhub No. 90 Tahun 2015. 
Nomor 1 Tahun 2009 tentang

Penerbangan.

\section{2) Peraturan Pemerintah}

Peraturan Pemerintah yang mendasari terbitnya Permenhub No. 90 Tahun 2015 ini ada 2 (dua) Peraturan Pemerintah sebagai berikut:

a) Peraturan Pemerintah Nomor 3 Tahun 2001 tentang Keamanan dan Keselamatan

Penerbangan. ${ }^{16}$

b) Peraturan Pemerintah Nomor 77 Tahun 2012 tentang Perusahaan Umum (Perum) Lembaga

Penyelenggara

Pelayanan Navigasi Penerbangan Indonesia. $^{17}$

3) Peraturan Presiden

Peraturan Presiden yang mendasari terbitnya Permenhub No. 90 Tahun 2015 ini ada 2 (dua)
Peraturan Presiden sebagai berikut:

a) Peraturan Presiden Nomor 7 Tahun 2015 tentang Organisasi Kementerian Negara. ${ }^{18}$

b) Peraturan Presiden Nomor 40 Tahun 2015 tentang Kementerian Perhubungan. ${ }^{19}$

\section{4) Peraturan Menteri}

Peraturan

Menteri

Presiden yang mendasari terbitnya Permenhub No. 90 Tahun 2015 ini ada 9 (sembilan) Peraturan Menteri sebagai berikut:

a) Peraturan Menteri Perhubungan Nomor KM 14 Tahun 2009 tentang Peraturan Keselamatan Penerbangan Sipil Bagian $170 \quad$ (Civil Aviation Safety Regulation Part 170) tentang Air Traffic Rules. ${ }^{20}$
${ }^{16}$ angka 2 bagian "Menimbang," Permenhub No. 90 Tahun 2015, Indonesia, Peraturan Pemerintah Tentang Keamanan dan Keselamatan Penerbangan, PP Nomor 3 Tahun 2001. Lembaran Negara Republik Indonesia Tahun 2001 Nomor 9, Tambahan Lembaran Negara Republik Indonesia Nomor 4075 .

${ }^{17}$ angka 3 bagian "Menimbang," Permenhub No. 90 Tahun 2015, Indonesia, Peraturan Pemerintah Tentang Perusahaan Umum (Perum) Lembaga Penyelenggara Pelayanan Navigasi Penerbangan Indonesia, PP Nomor 77 Tahun 2012. Lembaran Negara Republik Indonesia Tahun 2012 Nomor 176. ${ }^{18}$ angka 4 bagian "Menimbang," Permenhub No. 90 Tahun 2015, Presiden Republik Indonesia, Peraturan Presiden Tentang
Organisasi Kementerian Negara, Perpres Nomor 7 Tahun 2015. Lembaran Negara Republik Indonesia Tahun 2015 Nomor 5.

${ }^{19}$ angka 5 bagian "Menimbang,"

Permenhub No. 90 Tahun 2015, Presiden Republik Indonesia, Peraturan Presiden Tentang Kementerian Perhubungan, Perpres Nomor 40 Tahun 2015. Lembaran Negara Republik Indonesia Tahun 2015 Nomor 75.

${ }^{20}$ angka 6 bagian "Menimbang," Permenhub No. 90 Tahun 2015, Kementerian Perhubungan R.I., Peraturan Menteri Perhubungan Tentang Keselamatan Penerbangan Sipil Bagian 170 (Civil Aviation Safety Regulation Part 170) tentang Air Traffic Rules, Permenhub Nomor KM 14 Tahun 2009. 
b) Peraturan Menteri Perhubungan Nomor KM 60 Tahun 2010 tentang Organisasi dan Tata Kementerian Perhubungan sebagaimana diubah terakhir dengan Peraturan Menteri Perhubungan Nomor PM 68 Tahun 2013. ${ }^{21}$

c) Peraturan Menteri Perhubungan Nomor KM 49 Tahun 2011 tentang Peraturan Keselamatan Penerbangan Sipil Bagian 172 (Civil Aviation Safety Regulation Part 172) tentang Penyelenggara Pelayanan Lalu Lintas Penerbangan Sipil (Air Traffic Service Provider). ${ }^{22}$

d) Peraturan Menteri Perhubungan Nomor PM 55 Tahun 2011 tentang Peraturan Keselamatan $\begin{array}{lr}\text { Penerbangan } & \text { Sipil } \\ \text { Bagian 176 } & \text { (Civil } \\ \text { Aviation } & \text { Safety }\end{array}$

Regulation Part 176) tentang Pencarian dan Pertolongan (Search and Rescue). ${ }^{23}$

e) Peraturan Menteri Perhubungan Nomor PM 57 Tahun 2011 tentang Peraturan Keselamatan Penerbangan Sipil Bagiah 171 (Civil Aviation Safety Regulation Part 171) tentang Penyelenggara Pelayanan

Telekomunikasi Penerbangan (Aeronautical Telecommunication Service Provider) sebagaimana telah diubah terakhir dengan Peraturan Menteri Perhubungan Nomor PM 38 Tahun $2014 .{ }^{24}$
${ }^{21}$ angka 7 bagian "Menimbang," Permenhub No. 90 Tahun 2015, Kementerian Perhubungan R.I., Peraturan Menteri Perhubungan Tentang Organisasi dan Tata Kementerian Perhubungan, Permenhub Nomor KM 60 Tahun 2010. Terakhir diubah dengan Peraturan Menteri Perhubungan Nomor PM 68 Tahun 2013

${ }^{22}$ angka 8 bagian "Menimbang," Permenhub No. 90 Tahun 2015, Kementerian Perhubungan R.I., Peraturan Menteri Perhubungan Tentang Peraturan Keselamatan Penerbangan Sipil Bagian 172 (Civil Aviation Safety Regulation Part 172) tentang Penyelenggara Pelayanan Lalu Lintas Penerbangan Sipil (Air Traffic Service Provider), Permenhub Nomor KM 49 Tahun 2011.

${ }^{23}$ angka 9 bagian "Menimbang," Permenhub No. 90 Tahun 2015, Kementerian
Perhubungan R.I., Peraturan Menteri Perhubungan Tentang Peraturan Keselamatan Penerbangan Sipil Bagian 176 (Civil Aviation Safety Regulation Part 176) tentang Pencarian dan Pertolongan (Search and Rescue), Permenhub Nomor PM 55 Tahun 2011.

${ }^{24}$ angka 10 bagian "Menimbang," Permenhub No. 90 Tahun 2015, Kementerian Perhubungan R.I., Peraturan Menteri Perhubungan Tentang Peraturan Keselamatan Penerbangan Sipil Bagiah 171 (Civil Aviation Safety Regulation Part 171) tentang Penyelenggara Pelayanan Telekomunikasi Penerbangan (Aeronautical Telecommunication Service Provider), Permenhub Nomor PM 57 Tahun 2011. Terakhir diubah dengan Peraturan Menteri Perhubungan Nomor PM 38 Tahun 2014. 
f) Peraturan Menteri

Perhubungan Nomor

PM 9 Tahun 2015

tentang Peraturan

Keselamatan

Penerbangan Sipil

Bagia 174 (Civil

Aviation Safety

Regulation Part 174)

tentang Pelayanan

Informasi Meteorologi

Penerbangan

(Aeronautical

Meteorological

Information

Services). ${ }^{25}$

g) Peraturan Menteri

Perhubungan Nomor

PM 44 Tahun 2015

tentang Peraturan

Keselamatan

Penerbangan Sipil

Bagian 173 (Civil

Aviation Safety

Regulation Part 173)

tentang Perancangan

Prosedur Penerbangan

(Flight

ProcedureDesign). ${ }^{26}$
${ }^{25}$ angka 11 bagian "Menimbang,"

Permenhub No. 90 Tahun 2015, Kementerian Perhubungan R.I., Peraturan Menteri Perhubungan Tentang Peraturan Keselamatan Penerbangan Sipil Bagia 174 (Civil Aviation Safety Regulation Part 174) tentang Pelayanan Informasi Meteorologi Penerbangan (Aeronautical Meteorological Information Services), Permenhub Nomor PM 9 Tahun 2015

${ }^{26}$ angka 12 bagian "Menimbang," Permenhub No. 90 Tahun 2015, Kementerian Perhubungan R.I., Peraturan Menteri Perhubungan Tentang Peraturan Keselamatan Penerbangan Sipil Bagian 173 (Civil Aviation Safety Regulation Part 173) tentang Perancangan Prosedur Penerbangan (Flight ProcedureDesign), Permenhub Nomor PM44 Tahun 2015. h) Peraturan Menteri Perhubungan Nomor PM 55 Tahun 2015 tentang Peraturan Keselamatan Penerbangan Sipil Bagian 139 (Civil Aviation Safety Regulations Part 139) tentang Bandar Udara (Aerodrome). ${ }^{27}$

i) Peraturan Menteri Perhubungan Nomor PM 60 Tahun 2015 tentang Peraturan Keselamatan Penerbangan Sipil Bagian 175 (Civil Aviation Safety Regulation Part 175) tentang Pelayanan Informasi

Aeronautika (Aeronautical Information Service).$^{28}$

c. Permenhub No. 90 Tahun 2015 hanya terdiri dari 3 (tiga) pasal saja.

d. Permenhub No. 90 Tahun 2015 ditetapkan oleh Menteri

${ }^{27}$ angka 13 bagian "Menimbang," Permenhub No. 90 Tahun 2015, Kementerian Perhubungan R.I., Peraturan Menteri Perhubungan Tentang Peraturan Keselamatan Penerbangan Sipil Bagian 139 (Civil Aviation Safety Regulations Part 139) tentang Bandar Udara (Aerodrome), Permenhub Nomor PM 55 Tahun 2015.

${ }^{28}$ angka 14 bagian "Menimbang," Permenhub No. 90 Tahun 2015, Kementerian Perhubungan R.I., Peraturan Menteri Perhubungan Tentang Peraturan Keselamatan Penerbangan Sipil Bagian 175 (Civil Aviation Safety Regulation Part 175) tentang Pelayanan Informasi Aeronautika (Aeronautical Information Service), Permenhub Nomor PM 60 Tahun 2015. 
Perhubungan pada tanggal 12 Mei 2015.

e. Permenhub No. 90 Tahun 2015 diundangkan oleh Menteri Hukum Dan HAM Republik Indonesia pada tanggal 12 Mei 2015, dengan menempatkannya pada Berita Negara Republik Indonesia Tahun 2015 Nomor 723.

f. Permenhub No. 90 Tahun 2015 mulai berlaku pada tanggal di undangkan yaitu sejak tanggal 12 Mei 2015.

g. Sistematika isi Permenhub No. 90 Tahun 2015 berdasarkan Lampiran II Permenhub No. 90 Tahun 2015 pada pokoknya adalah sebagai berikut:

1) Pendahuluan berisi Penerapan dan definisi.

2) Ketentuan Umum Pengoperasian Sistem Pesawat Udara Tanpa Awak

3) Ketentuan Khusus Pengoperasian Sistem Pesawat Udara Tanpa Awak

4) Sistem Pesawat Udara Tanpa Awak Mempunyai Batasa Penggunaan Berdasaran Peralatan Yang Dibawakannya.

5) Sanksi

Permenhub No. 90 Tahun 2015 ini terdapat kekurangan dalam landasan hukumnya yang hanya mengacu kepada 1 (satu) Undangundang saja, yaitu Undangundang Penerbangan saja tanpa mengacu kepada Undang-undang lain yang berkaitan dengan kementerian negara dana pembentukan peraturan perudang-undangan.

Seyogya Permenhub No. 90 Tahun 2015 mencantumkan juga UU Kementerian Negara dan UU Pembentukan Peraturan Perundang-undangan. UU Kementerian Negara perlu dijadikan landasan hukum dalam Permenhub No. 90 Tahun 2015 tersebut, agar dapat dipahami bahwa Menteri berdasarkan UU Kemeneterian Negara memiliki kewenangan untuk membuat peraturan berkenaan dengan lingkup pelaksanaan tugas dan fungsi di bidangnya.

Demikian juga Permenhub No. 90 Tahun 2015 harus memperhatikan UU Pembentukan Peraturan Perundang-undangan agar materi muatan dalam Permenhub No. 90 Tahun 2015 tersebut selaras dengan materi muatan suatu Peraturan Menteri sebagaimana dimaksud dalam UU Pembentukan Peraturan Perundang-undangan. Selain itu seyogyanya dalam penyusunan Permenhub No. 90 Tahun 2015, Kementerian perhubungan memperhatikan teknis penulisan perundang-undangan pada umumnya, teknis penulisan suatu peraturan menteri pada khususnya, berkenaan dengan penulisan istilah bahasa asing.

Ditemukan adanya kelalaian kementerian perhubungan dalam penulisan istilah bahasa asing 
dalam hal ini bahasa Inggeris dalam Lampiran Permenhub No. 90 Tahun 2015 tersebut pada bagian definisi yaitu angka 1.2.1., 1.2.6., 1.2.7., dimana dinyatakan sebagai berikut:

"1.2.1. Flight plan adalah ..... dst (....."

"1.2.6. Controlled airspace adalah ..... dst ......"

"1.2.7. Uncontrolled airspace adalah ..... dst ......"

Pada angka 254 Lampiran II UU Pembentukan Peraturan Perundang-undangan dinyatakan sebagai berikut:

"254. Pengunaan kata, frasa atau istilah bahasa asing hanya digunakan di dalam penjelasan Peraturan Perundang-undangan. Kata, frasa atau istilah bahasa asing itu didahului oleh padanannya dalam Bahasa Indonesia, ditulis miring dan diletkakkan diantara tanda baca kurung ( ).

\section{Contoh:}

1. penghinaan terhadap peradilan (contempt of court)

2. penggabungan (merger)."

Apabila penulisan istilah bahasa asing dalam hal ini bahasa Inggeris dalam Permenhub No. 90 Tahun 2015 tersebut pada bagian definisi yaitu angka 1.2.1., 1.2.6., 1.2.7., diselaraskan dengan ketentuan angka 254 Lampiran II UU Pembentukan Peraturan
Perundang - undangan, seyogyanya penulisannya adalah sebagai berikut:

"1.2.1. Rencana terbang (flight plan) adalah ..... dst ......"

"1.2.6. ....... (controlled airspace) adalah ..... dst ..... ."

"1.2.7. ....... (uncontrolled airspace) adalah ..... dst ......"

Dengan demikian penulisan istilah bahasa asing dalam hal ini bahasa Inggeris dalam Permenhub No. 90 Tahun 2015 tersebut pada bagian definisi yaitu angka 1.2.1., 1.2.6., 1.2.7., tidak selara dengan ketentuan angka 254 Lampiran II UU Pembentukan Peraturan Perundang-undangan.

Lebih lanjut Permenhub No. 90 Tahun 2015 tersebut ditelaah, ditemukan setidaknya 2 (dua) istilah yang tidak diberikan definisinya pada bagian 1.2. Lampiran Permenhub No. 90 Tahun 2015 yaitu definisi ruang udara dan definisi sistem pesawat udara tanpa awak.

Peraturan perundang-undangan yang menjadi landasan hukum Permenhub No. 90 Tahun 2015 berupa Undang-undang Penerbangan dan PP No. 3 Tahun 2001 juga tidak memberikan dan juga tidak mengatur definisi ruang udara dan definisi sistem pesawat udara tanpa awak.

Setelah dilakukan penelitian terhadap beberapa peraturan perundang-undangan, penulis menemukan definisi ruang udara 
tersebut diatur dalam Undangundang Nomor 21 Tahun 2013 Tentang Keantariksaan. ${ }^{29}$

Pasal 1 angka 3 UU Nomor 21 Tahun $2013 \quad$ Tentang Keantariksaan dinyatakan sebagai berikut:

"Ruang Udara adalah ruang yang mengelilingi dan melingkupi seluruh permukaan bumi yang mengandung udara yang bersifat gas."

Sedangkan definisi sistem pesawat udara tanpa awak dalam Permenhub No. 90 Tahun 2015 maupun dalam berbagai peraturan perundang-undangan lainnya belum penulis temukan.

Hal lain yang perlu dicermati dalam Lampiran Permenhub No. 90 Tahun 2015 tersebut adalah angka 4.2., 4.3., 4.4 .

Angka 4.2. Lampiran Permenhub No. 90 Tahun 2015 menentukan sebagai berikut:

"4.2. Dalam hal sistem pesawat udara tanpa awak digunakan untuk kepentingan pemotretan, pemfilman dan pemetaan, harus melampirkan surat izin dari institusi yang berwenang dan

${ }^{29}$ Indonesia, Undang-Undang Tentang Keantariksaan, UU Nomor 21 Tahun 2013. Lembaran Negara Republik Indonesia Tahun 2013 Nomor 133, Tambahan Lembaran Negara Republik Indonesia Nomor 5435. Untuk selanjutnya dalam penulisan ini akan dan cukup disebut "UU Keantariksaan" atau "UU Nomor 21 Tahun 2013."
Pemerintah Daerah yang wilayahnya akan dipotret, difilmkan atau dipetakan."

Ketentuan angka 4.2. Lampiran Permenhub No. 90 Tahun 2015 berkaitan dengan berbagai peraturan perundang-undangan lain sebagai berikut:

a. untuk kepentingan pemotretan, pemfilman dan pemetaan,

Untuk kepentingan pemotretan, pemfilman dan pemetaan tersebut terkait dengan berbagai Undang-undang lainnya yang mengatur kegiatan kepentingan pemotretan, pemfilman dan pemetaan tersebut antara lain sebagai berikut:

1) Undang-undang Hak Cipta

$\begin{array}{lr}\text { Kegiatan } & \text { pemotretan } \\ \text { merupakan } & \text { kegiatan }\end{array}$
pengambilan gambar berupa gambar orang dan atau benda lainnya, dimana terhadap hasil pemotretan tersebut terdapat hak ekonomi atas pemotretan tersebut.

Hak ekonomi atas hasil pemotretan tersebut diatur dalam Pasal 12 Undangundang Hak Cipta $^{30}$ yang berbunyi sebagai berikut:

\footnotetext{
${ }^{30}$ Indonesia, Undang-Undang Tentang Hak Cipta,
} UU Nomor 28 Tahun 2014. Lembaran Negara Republik Indonesia Tahun 2014 Nomor 266, Tambahan Lembaran Negara Republik Indonesia Nomor 5599. Untuk selanjutnya dalam penulisan ini akan dan cukup disebut "UU Hak Cipta" atau "UU Nomor 28 Tahun 2014." UU Nomor 28 Tahun 2014 mulai berlaku sejak diundangkan pada tanggal 16 Oktober 2014. UU Nomor 28 Tahun 2014 


Setiap Orang
dilarang
melakukan
Penggunaan
Secara
Komersial,
Penggandaan,
Pengumuman,
Pendistribusian,
dan/atau atas
Komunikasi atas
Potret yang
dibuatnya guna
kepentingan
reklame atau
periklanan secara
komersial tanpa
persetujuan
tertulis dari
orang yang
dipotret atau ahli
warisnya.
Penggunaan
Secara
Komersial,
Penggandaan,
Pengumuman,
Pendistribusian,
dan/atau

mencabut dan menggantikan UU Nomor 19 Tahun 2002 Tentang Hak Cipta. Indonesia, Undang-Undang Tentang Hak Cipta, UU Nomor 19 Tahun 2002. Lembaran Negara Republik Indonesia Tahun 2002 Nomor 85, Tambahan Lembaran Negara Republik Indonesia Nomor 4220.

${ }^{31}$ Pasal 115 UU Hak Cipta "Setiap Orang yang tanpa persetujuan dari orang yang dipotret atau ahli warisnya melakukan Penggunaan Secara Komersial, Penggandaan, Pengumuman, Pendistribusian, atau Komunikasi atas Potret sebagaimana dimaksud dalam Pasal 12 untuk kepentingan reklame atau periklanan untuk Penggunaan Secara Komersial baik dalam media elektonik maupun non elektronik, dipidana dengan pidana denda
Komunikasi
Potret
sebagaimana
dimaksud pada
ayat (1) yang
memuat Potret 2
(dua) orang atau
lebih, wajib
meminta
persetujuan dari
orang yang ada
dalam Potret
atau ahli
warisnya."

Pelanggaran pidana atas Pasal 12 UU Hak Cipta tersebut dihukum dengan pidana denda paling banyak Rp 500.000.000,- (lima ratus juta rupiah) berdasarkan ketentuan Pasal $115^{31}$ UU Hak Cipta.

b. UU Pemerintahan Daerah

Kegiatan pemotretan,
pemfilman dan pemetaan
tersebut harus mendapat izin
kepala daerah sebagaimana
dimaksud dalam UU
Pemerintahan Daerah ${ }^{32}$ baik dari

paling banyak Rp500.000.000,00 (lima ratus juta rupiah)."

${ }^{32} \mathrm{UU}$ Pemerintahan Daerah yang berlaku saat ini adalah UU Nomor 23 Tahun 2014 Tentang Pemerintahan Daerah. UU Nomor 23 Tahun 2014 mulai berlaku sejak diundangkan pada tanggal 02 Oktober 2014. UU Nomor 23 Tahun 2014 mencabut dan menggantikan UU Nomor 32 Tahun 2004 Tentang Pemerintahan Daerah. UU Nomor 23 Tahun 2014 telah mengalami perubahan dengan Peraturan Pemerintah Pengganti Undang-undang Nomor 2 Tahun 2014 dan UU Nomor 2 Tahun 2015. Indonesia, Undang-Undang Tentang Pemerintahan Daerah, UU Nomor 23 Tahun 2014. Lembaran Negara Republik Indonesia Tahun 2014 Nomor 244, Tambahan Lembaran Negara Republik Indonesia 


$\begin{array}{lrr}\text { Gubernur } & \text { sebagai } & \text { Kepala } \\ \text { Daerah Provinsi, } & \text { Walikota } \\ \text { sebagai Kepala } & \text { Daerah } \\ \text { Kotamadya, Bupati } & \text { sebagai } \\ \text { kepala daerah kabupaten. }\end{array}$

Angka 4.3. dan 4.4. Lampiran Permenhub No. 90 Tahun 2015 menentukan sebagai berikut:

"44.3. Sistem pesawat udara tanpa awak dengan Peralatan Pertanian (penyemprot hama dan/atau penabur benih) hanya diperbolehkan beroperasi pada areal pertanian/perkebunan yang dijelaskan dalam pengajuan rencana terbang (flightplan).

4.4. Kegiatan penyemprotan hama dan/atau penaburan benih dengan menggunakan teknologi sistem pesawat udara tanpa awak diizinkan apabila dalam radius $500 \mathrm{~m}$ dari batas terluar areal pertanian/perkebunan dimaksud tidak ada pemukiman penduduk."

Operator pesawat udara tanpa awak (drone) harus memperhatikan ketentuan angka 4.3. dan 4.4. Lampiran Permenhub No. 90 Tahun 2015 berkenaan dengan keterkaitannya dengan berbagai peraturan perundang-undangan lain, antara lain, sebagai berikut:

a. UU Nomor 5 Tahun 1960 tentang Peraturan Dasar Pokok-Pokok Agraria. $^{33}$
Nomor 5587. Untuk selanjutnya dalam penulisan ini akan dan cukup disebut "UU Pemerintahan Daerah" atau "UU Pemda" atau "UU Nomor 23 Tahun 2014." Indonesia, Peraturan Pemerintah Pengganti UndangUndang tentang Perubahan atas Undang-Undang Nomor 23 Tahun 2014 tentang Pemerintahan Daerah, PERPUU Nomor 2 Tahun 2014. Lembaran Negara Republik Indonesia Tahun 2014 Nomor 246, Tambahan Lembaran Negara Republik Indonesia Nomor 5589. Indonesia, Undang-Undang Tentang Penetapan Peraturan Pemerintah Pengganti Undang-Undang Nomor 2 Tahun 2014 Tentang Perubahan Atas Undang-Undang Nomor 23 Tahun 2014 Tentang Pemerintahan Daerah Menjadi Undang-Undang, UU Nomor 2 Tahun 2015. Lembaran Negara Republik Indonesia Tahun 2015 Nomor 24 Tambahan Lembaran Negara Republik Indonesia Nomor 5589. UU Nomor 32 Tahun 2004 telah diubah dengan PERPUU Nomor 3 Tahun 2005 Jo. UU No. 8 Tahun 2005, terakhir diubah dengan UU Nomor 12 Tahun 2008. Indonesia, Peraturan Pemerintah Pengganti Undang-Undang tentang
Perubahan Atas Undang-Undang Nomor 32 Tahun 2004 tentang Pemerintahan Daerah, PERPUU Nomor 3 Tahun 2005. Lembaran Negara Republik Indonesia Tahun 2004 Nomor 35, Tambahan Lembaran Negara Republik Indonesia Nomor 4493. Indonesia, Undang-undang tentang Penetapan Peraturan Pemerintah Pengganti Undang-Undang Nomor 3 Tahun 2005 tentang Perubahan atas Undang-Undang Nomor 32 Tahun 2004 tentang Pemerintahan Daerah Menjadi Undang-Undang, UU Nomor 8 Tahun 2005. Lembaran Negara Republik Indonesia Tahun 2005 Nomor 108, Tambahan Lembaran Negara Republik Indonesia Nomor 4548. Indonesia, Undang-undang tentang Perubahan Kedua Atas Undang-Undang Nomor 32 Tahun 2004 tentang Pemerintahan Daerah, UU Nomor 12 Tahun 2008. Lembaran Negara Republik Indonesia Tahun 2008 Nomor 59, Tambahan Lembaran Negara Republik Indonesia Nomor 4844

${ }^{33}$ Indonesia, Undang-Undang Tentang Peraturan Dasar Pokok-Pokok Agraria, UU Nomor 
b. UU Nomor 5 Tahun 1990 tentang Konservasi Sumber Daya Alam Hayati dan Ekosistemnya. ${ }^{34}$

c. UU Nomor 12 Tahun 1992 tentang Sistem Budidaya Tanaman. ${ }^{35}$

d. Undang-undang Nomor 16 Tahun 1992 tentang Karantina Hewan, Ikan, dan Tumbuhan. ${ }^{36}$

e. Undang-Undang Nomor 41 Tahun 1999 tentang Kehutanan. ${ }^{37}$

f. Undang-Undang Nomor 29 Tahun 2000 tentang Perlindungan Varietas Tanaman. ${ }^{38}$

5 Tahun 1960. Lembaran Negara Republik Indonesia Tahun 1960 Nomor 104, Tambahan Lembaran Negara Republik Indonesia Nomor 2043. Untuk selanjutnya dalam penulisan ini akan dan cukup disebut "UU Pokok Agraria" atau "UU Nomor 5 Tahun 1960."

${ }^{34}$ Indonesia, Undang-Undang Tentang Konservasi Sumber Daya Alam Hayati dan Ekosistemnya, UUNomor 5 Tahun 1990. Lembaran Negara Republik Indonesia Tahun 1990 Nomor 49, Tambahan Lembaran Negara Republik Indonesia Nomor 3419

${ }^{35}$ Indonesia, Undang-Undang Tentang Sistem Budidaya Tanaman, UU Nomor 12 Tahun 1992. Lembaran Negara Republik Indonesia Tahun 1992 Nomor 46, Tambahan Lembaran Negara Republik Indonesia Nomor 3478.

${ }^{36}$ Indonesia, Undang-Undang Tentang Karantina Hewan, Ikan, dan Tumbuhan, UU Nomor 16 Tahun 1992. Lembaran Negara Republik Indonesia Tahun 1992 Nomor 56, Tambahan Lembaran Negara Republik Indonesia Nomor 3482.

${ }^{37}$ Indonesia, Undang-Undang Tentang Kehutanan, UU Nomor 41 Tahun 1999. Lembaran Negara Republik Indonesia Tahun 1999 Nomor 167, Tambahan Lembaran Negara Republik Indonesia Nomor 3888.

$$
{ }^{38} \text { Indonesia, Undang-Undang Tentang }
$$

g. Undang-Undang Nomor 18 Tahun 2002 tentang Sistem Nasional Penelitian dan Pengembangan dan Penerapan Ilmu Pengetahuan dan Teknologi. ${ }^{39}$

h. Undang-Undang Nomor 31 Tahun 2004 tentang Perikanan. ${ }^{40}$

i. Undang-Undang Nomor 16 Tahun 2006 tentang Sistem Penyuluhan Pertanian, Perikanan, dan Kehutanan. ${ }^{41}$

j. Undang-Undang Nomor 18 Tahun 2009 tentang Peternakan dan Kesehatan Hewan. ${ }^{42}$

Perlindungan Varietas Tanaman, UU Nomor 29 Tahun 2000. Lembaran Negara Republik Indonesia Tahun 2000 Nomor 241, Tambahan Lembaran Negara Republik Indonesia Nomor 4043.

${ }^{39}$ Indonesia, Undang-Undang Tentang Sistem Nasional Penelitian dan Pengembangan dan Penerapan Ilmu Pengetahuan dan Teknologi, UU Nomor 18 Tahun 2002. Lembaran Negara Republik Indonesia Tahun 2002 Nomor 84, Tambahan Lembaran Negara Republik Indonesia Nomor 4219.

${ }^{40}$ Indonesia, Undang-Undang Tentang Perikanan, UU Nomor 31 Tahun 2004. Lembaran Negara Republik Indonesia Tahun 2004 Nomor 148, Tambahan Lembaran Negara Republik Indonesia Nomor 4433.

${ }^{41}$ Indonesia, Undang-Undang Tentang Sistem Penyuluhan Pertanian, Perikanan, dan Kehutanan, UU Nomor 16 Tahun 2006. Lembaran Negara Republik Indonesia Tahun 2006 Nomor 92, Tambahan Lembaran Negara Republik Indonesia Nomor 4660.

${ }^{42}$ Indonesia, Undang-Undang Tentang Peternakan dan Kesehatan Hewan, UU Nomor 18 Tahun 2009. Lembaran Negara Republik Indonesia Tahun 2009 Nomor 84, Tambahan Lembaran Negara Republik Indonesia Nomor 5015. 
k. Undang-Undang Nomor

32 Tahun 2009 tentang

Perlindungan dan

Pengelolaan Lingkungan

Hidup. ${ }^{43}$

1. Undang-Undang Nomor

41 Tahun 2009 tentang

Perlindungan Lahan

Pertanian Pangan

Berkelanjutan. ${ }^{44}$

m. Undang-Undang Nomor

13 Tahun 2010 tentang

Hortikultura $^{45}$

n. Undang-Undang Nomor

4 Tahun 2011 tentang

Informasi Geospasial. ${ }^{46}$

o. Undang-Undang Nomor

18 Tahun 2012 tentang

Pangan. ${ }^{47}$

p. Undang-Undang Nomor

19 Tahun 2013 Tentang

Perlindungan Dan

Pemberdayaan Petani. ${ }^{48}$

q. Undang-Undang Nomor

39 Tahun 2014 tentang

Perkebunan. ${ }^{49}$
Terakhir yang dapat dicermati dalam Lampiran Permenhub No. 90 Tahun 2015 tersebut yang terdapat pada angka 5 dinyatakan sebagai berikut:

"5. Sanksi

$\begin{array}{lr}\text { Kelalaian } & \text { dan/atau } \\ \text { penyimpangan } & \text { terhadap } \\ \text { pelaksanaan } & \text { ketentuan } \\ \text { sebagaimana } & \text { dimaksud } \\ \text { peraturan ini, } & \text { dikenakan } \\ \text { sanksi sesuai } & \text { dengan } \\ \text { ketentuan } & \text { peraturan } \\ \text { perundang-undangan." }\end{array}$

Pelanggaran terhadap ketentuan-ketentuan yang telah diatur dalam Permenhub No. 90 Tahun 2015 ini mengacu kepada ketentuan Undang-undang yang menjadi landasan hukum diterbitkannya Permenhub No. 90 Tahun 2015 tersebut, yaitu sanksi-

\begin{abstract}
${ }^{43}$ Indonesia, Undang-Undang Tentang Perlindungan dan Pengelolaan Lingkungan Hidup, UU Nomor 32 Tahun 2009. Lembaran Negara Republik Indonesia Tahun 2009 Nomor 140, Tambahan Lembaran Negara Republik Indonesia Nomor 5059.
\end{abstract}

${ }^{44}$ Indonesia, Undang-Undang Tentang Perlindungan Lahan Pertanian Pangan Berkelanjutan, UU Nomor 41 Tahun 2009. Lembaran Negara Republik Indonesia Tahun 2009 Nomor 149, Tambahan Lembaran Negara Republik Indonesia Nomor 5068.

${ }^{45}$ Indonesia, Undang-Undang Tentang Hortikultura, UU Nomor 13 Tahun 2010. Lembaran Negara Republik Indonesia Tahun 2010 Nomor 132, Tambahan Lembaran Negara Republik Indonesia Nomor 5170.

${ }^{46}$ Indonesia, Undang-Undang Tentang Informasi Geospasial, UU Nomor 4 Tahun 2011. Lembaran Negara
Republik Indonesia Tahun 2011 Nomor 49, Tambahan Lembaran Negara Republik Indonesia Nomor 5214.

${ }^{47}$ Indonesia, Undang-Undang Tentang Pangan, UU Nomor 18 Tahun 2012. Lembaran Negara Republik Indonesia Tahun 2012 Nomor 227, Tambahan Lembaran Negara Republik Indonesia Nomor 5360.

${ }^{48}$ Indonesia, Undang-Undang Tentang Perlindungan Dan Pemberdayaan Petani, UU Nomor 19 Tahun 2013. Lembaran Negara Republik Indonesia Tahun 2013 Nomor 131 Tambahan Lembaran Negara Republik Indonesia Nomor 5433.

${ }^{49}$ Indonesia, Undang-Undang Tentang Perkebunan, UU Nomor 39 Tahun 2014. Lembaran Negara Republik Indonesia Tahun 2014 Nomor 308, Tambahan Lembaran Negara Republik Indonesia Nomor 5613. 
sanksi yang diatur dalam UU

Penerbangan, khusus

berkenaan dengan sanksi

pidana seperti ketentuan

Pasal 411, Pasal 431 dan

Pasal 432.

Selain sanksi yang diatur dalam UU Penerbangan, sanksi lain yang diatur dalam peraturan perundangundangan lainnya yang berkaitan dengan pelaksanaan kegiatan sistem pesawat udara tanpa awak (drone), antara lain yang diatur dalam UU Hak Cipta, UU Pemerintahan Daerah, UU Informasi Geospasial, UU Telekomunikasi, UU Informasi Dan Transaksi Elektronik, dan Undangundang lainnya.

\section{Penutup}

\section{A. Kesimpulan}

Dari uraian yang telah diuraikan diatas, dapat disimpulkan sebagai berikut:

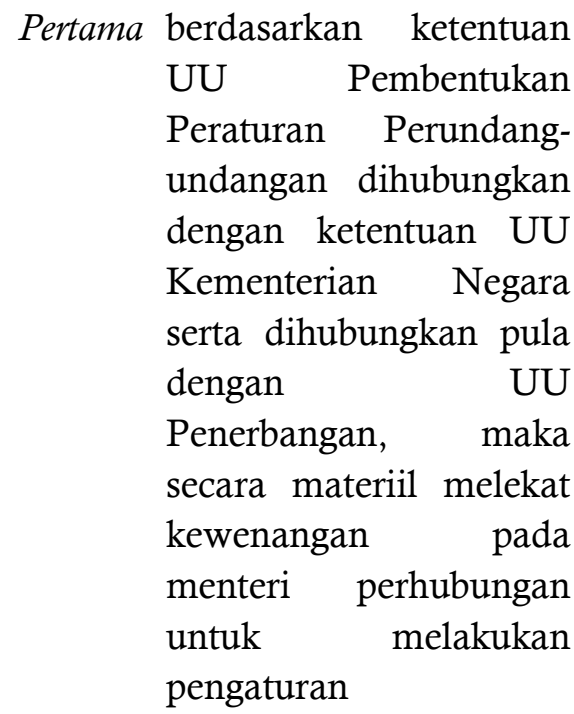

pengendalian

pengoperasian pesawat udara tanpa awak (drone), dalam bentuk suatu peraturan menteri perhubungan. Dan ditinjau dari segi kemanfaatan,pengaturan pengendalian

pengoperasian pesawat udara tanpa awak (drone), dalam bentuk suatu peraturan menteri perhubungan,

dimaksudkan dalam rangka menjaga keselamatan operasional penerbangan di ruang udara. yang dilayani Indonesia dari kemungkinan bahaya (hazard) yang ditimbulkan karena pengoperasian pesawat udara tanpa awak di ruang udara yang dilayani di Indonesia.

Kedua Permenhub No. 90 Tahun 2015 ditinjau dari segi ilmu dan teknik perudnang-undangan perlu disempurnakan dan diselaraskan melalui harmonisasi dengan berbagai peraturan perundang-undangan lainya, misalanya UU Pembentukan Peraturan Perundang-undangan, UU Telekomunikasi, UU Informasi dan transaksi elektronik, UU Keantariksaan, dan Undang-undang lainnya. 


\section{B. Rekomendasi}

Dalam rangka mendukung terwujudnya pengaturan hukum atas Pengendalian Pengoperasian Pesawat Udara Tanpa Awak (drone) di Ruang Wilayah Udara yang Dilayani Indonesia, maka disarankan hal-hal sebagai berikut:

$\begin{array}{rlr}\text { Pertama } & \text { perlu dilakukan } \\ \text { perubahan Undang- } & \text { Undang Penerbangan } \\ & \text { dengan menambahkan } \\ & \text { satu bab khusus } \\ & \text { berkenaan } r \text { dengan } \\ & \text { penerbangan pesawat } \\ & \text { udara tanpa awak } \\ & \text { (drone). }\end{array}$

$\begin{array}{rlr}\text { Kedua } & \text { perlu dilakukan } \\ & \text { harmonisasi peraturan } \\ & \text { perundang-undangan } \\ & \text { yang terkait dengan } \\ \text { penerbangan pesawat } & \text { udara tanpa awak } \\ & (\text { drone }) & \text { guna } \\ \text { memasikan } & \text { materi } \\ & \text { muatan, jenis peraturan } \\ & \text { perundang-undangan } \\ & \text { yang r menerima } \\ \text { delegasi dari Undang- } & \\ \text { undang Penerbangan. }\end{array}$

\section{Daftar Pustaka}

Buku:

Martono, K, dan Ahmad Sudiro, Hukum

Udara Nasional Dan Internasional Publik, Cet. 1, Jakarta : Rajagrafindo, 2012.
Pramono, Agus. Dasar-dasar Hukum Udara Dan Ruang Angkasa, Cet. 1, Bogor : Ghalia Indonesia, 2011.

Sadjijono, Memahami Beberapa Bab Pokok Hukum Administrasi, Cet. 1, Yogyakarta : Laksbang Pressindo, 2008

Perundang-Undangan:

Indonesia, Undang-Undang Tentang Peraturan Dasar Pokok-Pokok Agraria, UU Nomor 5 Tahun 1960. Lembaran Negara Republik Indonesia Tahun 1960 Nomor 104, Tambahan Lembaran Negara Republik Indonesia Nomor 2043.

Indonesia, Undang-Undang Tentang Konservasi Sumber Daya Alam Hayati dan Ekosistemnya, UU Nomor 5 Tahun 1990. Lembaran Negara Republik Indonesia Tahun 1990 Nomor 49, Tambahan Lembaran Negara Republik Indonesia Nomor 3419

Indonesia, Undang-Undang Tentang Sistem Budidaya Tanaman, UU Nomor 12 Tahun 1992. Lembaran Negara Republik Indonesia Tahun 1992 Nomor 46, Tambahan Lembaran Negara Republik Indonesia Nomor 3478 .

Indonesia, Undang-Undang Tentang Karantina Hewan, Ikan, dan Tumbuhan, UU Nomor 16 Tahun 1992. Lembaran Negara Republik Indonesia Tahun 1992 Nomor 56, Tambahan Lembaran Negara Republik Indonesia Nomor 3482 .

Indonesia, Undang-Undang Tentang Kehutanan, UU Nomor 41 Tahun 1999. Lembaran Negara Republik Indonesia Tahun 1999 Nomor 167, Tambahan Lembaran 
Negara Republik Indonesia Nomor 3888.

Indonesia, Undang-Undang Tentang Perlindungan Varietas Tanaman, UU Nomor 29 Tahun 2000. Lembaran Negara Republik Indonesia Tahun 2000 Nomor 241, Tambahan Lembaran Negara Republik Indonesia Nomor 4043.

Indonesia, Undang-Undang Tentang Sistem Nasional Penelitian dan Pengembangan dan Penerapan Ilmu Pengetahuan dan Teknologi, UU Nomor 18 Tahun 2002. Lembaran Negara Republik Indonesia Tahun 2002 Nomor 84, Tambahan Lembaran Negara Republik Indonesia Nomor 4219.

Indonesia, Undang-Undang Tentang Hak Cipta, UU Nomor 19 Tahun 2002. Lembaran Negara Republik Indonesia Tahun 2002 Nomor 85, Tambahan Lembaran Negara Republik Indonesia Nomor 4220 .

Indonesia, Undang-Undang Tentang Perikanan, UU Nomor 31 Tahun 2004. Lembaran Negara Republik Indonesia Tahun 2004 Nomor 148, Tambahan Lembaran Negara Republik Indonesia Nomor 4433.

Indonesia, Undang-undang tentang Perubahan Kedua Atas Undang-Undang Nomor 32 Tahun 2004 tentang Pemerintahan Daerah, UU Nomor 12 Tahun 2008. Lembaran Negara Republik Indonesia Tahun 2008 Nomor 59, Tambahan Lembaran Negara Republik Indonesia Nomor 4844.

Indonesia, Undang-undang tentang Penetapan Peraturan Pemerintah Pengganti
Undang-Undang Nomor 3 Tahun 2005 tentang Perubahan atas UndangUndang Nomor 32 Tahun 2004 tentang Pemerintahan Daerah Menjadi Undang-Undang, UU Nomor 8 Tahun 2005. Lembaran Negara Republik Indonesia Tahun 2005 Nomor 108, Tambahan Lembaran Negara Republik Indonesia Nomor 4548.

Indonesia, Undang-Undang Tentang Sistem Penyuluhan Pertanian, Perikanan, dan Kehutanan, UU Nomor 16 Tahun 2006. Lembaran Negara Republik Indonesia Tahun 2006 Nomor 92, Tambahan Lembaran Negara Republik Indonesia Nomor 4660.

Indonesia, Undang-Undang Tentang Kementerian Negara, UU Nomor 39 Tahun 2008. Lembaran Negara Republik Indonesia Tahun 2008 Nomor 116, Tambahan Lembaran Negara Republik Indonesia Nomor 4916.

Indonesia, Undang-Undang Tentang Penerbangan, UU Nomor 1 Tahun 2009. Lembaran Negara Republik Indonesia Tahun 2009 Nomor 1, Tambahan Lembaran Negara Republik Indonesia Nomor 4956.

Indonesia, Undang-Undang Tentang Peternakan dan Kesehatan Hewan, UU Nomor 18 Tahun 2009. Lembaran Negara Republik Indonesia Tahun 2009 Nomor 84, Tambahan Lembaran Negara Republik Indonesia Nomor 5015.

Indonesia, Undang-Undang Tentang Perlindungan dan Pengelolaan Lingkungan Hidup, UU Nomor 32 Tahun 2009. Lembaran Negara Republik Indonesia Tahun 2009 
Nomor 140, Tambahan Lembaran

Negara Republik Indonesia Nomor 5059 .

Indonesia, Undang-Undang Tentang Perlindungan Lahan Pertanian Pangan Berkelanjutan, UU Nomor 41 Tahun 2009. Lembaran Negara Republik Indonesia Tahun 2009 Nomor 149, Tambahan Lembaran Negara Republik Indonesia Nomor 5068.

Indonesia, Undang-Undang Tentang Hortikultura, UU Nomor 13 Tahun 2010. Lembaran Negara Republik Indonesia Tahun 2010 Nomor 132, Tambahan Lembaran Negara Republik Indonesia Nomor 5170.

Indonesia, Undang-Undang Tentang Informasi Geospasial, UU Nomor 4 Tahun 2011. Lembaran Negara Republik Indonesia Tahun 2011 Nomor 49, Tambahan Lembaran Negara Republik Indonesia Nomor 5214.

Indonesia, Undang-Undang Tentang Pembentukan Peraturan Perundangundangan, UU Nomor 12 Tahun 2011. Lembaran Negara Republik Indonesia Tahun 2011 Nomor 82, Tambahan Lembaran Negara Republik Indonesia Nomor 5234.

Indonesia, Undang-Undang Tentang Pangan, UU Nomor 18 Tahun 2012. Lembaran Negara Republik Indonesia Tahun 2012 Nomor 227, Tambahan Lembaran Negara Republik Indonesia Nomor 5360 .

Indonesia, Undang-Undang Tentang Perlindungan Dan Pemberdayaan Petani, UU Nomor 19 Tahun 2013. Lembaran Negara Republik Indonesia
Tahun 2013 Nomor 131 Tambahan Lembaran Negara Republik Indonesia Nomor 5433.

Indonesia, Undang-Undang Tentang Keantariksaan, UU Nomor 21 Tahun 2013. Lembaran Negara Republik Indonesia Tahun 2013 Nomor 133, Tambahan Lembaran Negara Republik Indonesia Nomor 5435.

Indonesia, Undang-Undang Tentang Pemerintahan Daerah, UU Nomor 23 Tahun 2014. Lembaran Negara Republik Indonesia Tahun 2014 Nomor 244, Tambahan Lembaran Negara Republik Indonesia Nomor 5587.

Indonesia, Undang-Undang Tentang Hak Cipta, UU Nomor 28 Tahun 2014. Lembaran Negara Republik Indonesia Tahun 2014 Nomor 266, Tambahan Lembaran Negara Republik Indonesia Nomor 5599 .

Indonesia, Undang-Undang Tentang Perkebunan, UU Nomor 39 Tahun 2014. Lembaran Negara Republik Indonesia Tahun 2014 Nomor 308, Tambahan Lembaran Negara Republik Indonesia Nomor 5613.

Indonesia, Undang-Undang Tentang Penetapan Peraturan Pemerintah Pengganti Undang-Undang Nomor 2 Tahun 2014 Tentang Perubahan Atas Undang-Undang Nomor 23 Tahun 2014 Tentang Pemerintahan Daerah Menjadi Undang-Undang, UU Nomor 2 Tahun 2015. Lembaran Negara Republik Indonesia Tahun 2015 Nomor 24 Tambahan Lembaran Negara Republik Indonesia Nomor 5589 
Indonesia, Peraturan Pemerintah Pengganti Undang-Undang tentang Perubahan atas Undang-Undang Nomor 23 Tahun 2014 tentang Pemerintahan Daerah, PERPUU Nomor 2 Tahun 2014. Lembaran Negara Republik Indonesia Tahun 2014 Nomor 246, Tambahan Lembaran Negara Republik Indonesia Nomor 5589.

Indonesia, Peraturan Pemerintah Pengganti Undang-Undang tentang Perubahan Atas Undang-Undang Nomor 32 Tahun 2004 tentang Pemerintahan Daerah, PERPUU Nomor 3 Tahun 2005. Lembaran Negara Republik Indonesia Tahun 2004 Nomor 35, Tambahan Lembaran Negara Republik Indonesia Nomor 4493.

Presiden Republik Indonesia, Peraturan Pemerintah Tentang Keamanan dan Keselamatan Penerbangan, PP Nomor 3 Tahun 2001. Lembaran Negara Republik Indonesia Tahun 2001 Nomor 9, Tambahan Lembaran Negara Republik Indonesia Nomor 4075.

Presiden Republik Indonesia, Peraturan Pemerintah Tentang Perusahaan Umum (Perum) Lembaga Penyelenggara Pelayanan Navigasi Penerbangan Indonesia, PP Nomor 77 Tahun 2012. Lembaran Negara Republik Indonesia Tahun 2012 Nomor 176.

Presiden Republik Indonesia, Peraturan Presiden Tentang Organisasi Kementerian Negara, Perpres Nomor 7 Tahun 2015. Lembaran Negara Republik Indonesia Tahun 2015 Nomor 5.

Presiden Republik Indonesia, Peraturan Presiden Tentang Kementerian Perhubungan, Perpres Nomor 40 Tahun
2015. Lembaran Negara Republik Indonesia Tahun 2015 Nomor 75.

Kementerian Perhubungan R.I., Peraturan Menteri Perhubungan Tentang Keselamatan Penerbangan Sipil Bagian 170 (Civil Aviation Safety Regulation Part 170) tentang Air Traffic Rules, Permenhub Nomor KM 14 Tahun 2009.

Kementerian Perhubungan R.I., Peraturan Menteri Perhubungan Tentang Organisasi dan Tata Kementerian Perhubungan, Permenhub Nomor KM 60 Tahun 2010. Terakhir diubah dengan Peraturan Menteri Perhubungan Nomor PM 68 Tahun 2013

Kementerian Perhubungan R.I., Peraturan Menteri Perhubungan Tentang Peraturan Keselamatan Penerbangan Sipil Bagian 172 (Civil Aviation Safety Regulation Part 172) tentang Penyelenggara Pelayanan Lalu Lintas Penerbangan Sipil (Air Traffic Service Provider), Permenhub Nomor KM 49 Tahun 2011.

Kementerian Perhubungan R.I., Peraturan Menteri Perhubungan Tentang Peraturan Keselamatan Penerbangan Sipil Bagian 176 (Civil Aviation Safety Regulation Part 176) tentang Pencarian dan Pertolongan (Search and Rescue), Permenhub Nomor PM 55 Tahun 2011.

Kementerian Perhubungan R.I., Peraturan Menteri Perhubungan Tentang Peraturan Keselamatan Penerbangan Sipil Bagiah 171 (Civil Aviation Safety Regulation Part 171) tentang Penyelenggara Pelayanan Telekomunikasi Penerbangan (Aeronautical Telecommunication Service Provider), Permenhub Nomor PM 57 Tahun 2011. Terakhir diubah dengan Peraturan Menteri Perhubungan Nomor PM 38 Tahun 2014.

Kementerian Perhubungan R.I., Peraturan Menteri Perhubungan Tentang Peraturan 
Keselamatan Penerbangan Sipil Bagia 174 (Civil Aviation Safety Regulation Part 174) tentang Pelayanan Informasi Meteorologi Penerbangan (Aeronautical Meteorological Information Services), Permenhub Nomor PM 9 Tahun 2015. Kementerian Perhubungan R.I., Peraturan Menteri Perhubungan Tentang Peraturan Keselamatan Penerbangan Sipil Bagian 173 (Civil Aviation Safety Regulation Part 173) tentang Perancangan Prosedur Penerbangan (Flight ProcedureDesign), Permenhub Nomor PM 44 Tahun 2015.

Kementerian Perhubungan R.I., Peraturan Menteri Perhubungan Tentang Peraturan Keselamatan Penerbangan Sipil Bagian 139 (Civil Aviation Safety Regulations Part 139) tentang Bandar Udara (Aerodrome), Permenhub Nomor PM 55 Tahun 2015.

Kementerian Perhubungan R.I., Peraturan Menteri Perhubungan Tentang Peraturan Keselamatan Penerbangan Sipil Bagian 175 (Civil Aviation Safety Regulation Part 175) tentang Pelayanan Informasi Aeronautika (Aeronautical Information Service), Permenhub Nomor PM 60 Tahun 2015.

Kementerian Perhubungan R.I., Peraturan Menteri Perhubungan Tentang Pengendalian Pengoperasian Pesawat Udara Tanpa Awak di Ruang Wilayah Udara yang Dilayani Indonesia, Permenhub Nomor PM 90 Tahun 2015.

Internet:

"Perlukah adanya Legislasi Drone Sipil?," http://www.koransindo.com/read/1013173/152/per lukah-adanya-legislasi-drone-sipil1434424227
"Pengaturan Drone Dilakukan Untuk Keselamatan Penerbangan," http://www.dephub.go.id/berita/ baca/pengaturan-drone-dilakukanuntuk-keselamatanpenerbangan/?cat $=\mathrm{QmVyaXRhfH}$ N1Y3Rpb24tNjU, diakses Kamis, 18 September 2015.

"Penggunaan Drone Sipil: Pro atau Kontra?,"

http://citizendaily.net/penggunaa n-drone-sipil-pro-atau-kontra, diakses Kamis, 18 September 2015. 